\title{
AN UNUSUAL CASE OF ACUTE PANCREATITIS ASSOCIATED WITH ACUTE HEPATITIS E VIRUS INFECTION
}

\author{
Kumar Himanshu1, Sushant Kumar Pathak2, Jaikant Lal Das ${ }^{3}$ \\ ${ }_{1}^{1}$ IIIrd Year Junior Resident, Department of General Medicine, PMCH, Patna. \\ 2IIIrd Year Junior Resident, Department of General Medicine, PMCH, Patna. \\ 3Professor and HOD, Department of General Medicine, PMCH, Patna.
}

\section{KEYWORDS}

Acute Pancreatitis, Hepatitis E, Fulminant, Non-Fulminant

\section{INTRODUCTION}

Acute pancreatitis is one of the uncommon extra-hepatic complication of hepatitis $\mathrm{E}$ virus. In medical literature, less than 50 cases have been documented so far. In spite of its rarity, the physician should remain alert to the possibility of pancreatitis in a patient of acute hepatitis E. Symptoms such as severe abdominal pain, restlessness or shock must warrant a search for underlying pancreatitis. It is important to recognise it at an early stage, as early constitution of treatment can help prevent the mortality associated with pancreatitis.
\end{abstract}

ABSTRACT

The coincidence of viral hepatitis and acute pancreatitis is well described. Most of the cases are related to acute hepatitis A or B; however, pancreatitis due to Hepatitis E Virus (HEV) infections are rare. Most cases of acute pancreatitis is associated with fulminant viral hepatitis; however, acute pancreatitis occurring in non-fulminant hepatitis is less commonly documented. The case presented here describes moderate pancreatitis in a young male, manifesting during the course of a non-fulminant acute hepatitis E infection.

HOW TO CITE THIS ARTICLE: Himanshu K, Pathak SK, Das JL. An unusual case of acute pancreatitis associated with acute hepatitis E virus infection. J. Evolution Med. Dent. Sci. 2016;5(72):5324-5325, DOI: 10.14260/jemds/2016/1206

\section{CASE REPORT}

A 21-year-male presented to the emergency in Patna Medical College with a history of severe abdominal pain and restlessness for two days. He was apparently well fifteen days back; he then complained of yellowish discoloration of urine followed by the sclera. Associated symptoms included anorexia, nausea, low-grade fever and arthralgia. He was taking advice from a local physician for these complaints with no improvement in symptoms. The day before admission in our hospital, he complained of severe epigastric pain which exacerbated on lying down and on taking meals. The pain was severe in intensity and did not respond to over-the-counter analgesics. The next day he felt restless and complained of diaphoresis and was rushed to our emergency.

At the time of admission, he was restless and perspiring excessively. His pulse rate was $120 /$ minute and he had a Blood Pressure of $70 / 40 \mathrm{mmHg}$. General examination revealed icterus with a greenish tinge and mild pallor. Abdominal examination revealed generalised tenderness and guarding over the epigastric area. No organs were palpable and the liver span was normal. Chest examination was normal. The cardiovascular examination was normal, but for tachycardia.

Financial or Other, Competing Interest: None.

Submission 27-07-2016, Peer Review 24-08-2016,

Acceptance 30-08-2016, Published 08-09-2016.

Corresponding Author:

Dr. Kumar Himanshu,

Junior Resident,

Department of Medicine,

Patna Medical College, Patna.

E-mail: rgtc2008@gmail.com

DOI: $10.14260 /$ jemds/2016/1206
Nervous system examination did not show any abnormality. The patient had never consumed alcohol, had never suffered from cholelithiasis or related diseases, had no history of any significant drug intake or any surgical procedures or history of any abdominal trauma, nor had he ever suffered from chronic medical illnesses such as Diabetes or Hypertension or Dyslipidaemia. His family history did not reveal anything significant.

A presumptive diagnosis of Acute Hepatitis complicated by Pancreatitis was made and the patient was admitted to our ICU. With intensive fluid management and supportive care, he showed improvement in his symptoms over the next few days and was discharged from the hospital 6 days later.

\section{His Investigations Revealed}

Hb 13.8 mg/dL, TLC 10700, DLC N71 L25 E2, RBS 106 mg/dL, Blood urea $31 \mathrm{mg} \%$ and serum creatinine $0.6 \mathrm{mg} \%$. The Liver Function Tests revealed a Total bilirubin of $16.20 \mathrm{mg} \%$ of which direct was $10.70 \mathrm{mg} \%$ and Indirect was $5.50 \mathrm{mg} \%$, AST was $718 \mathrm{U} / \mathrm{L}$, ALT was $751 \mathrm{U} / \mathrm{L}$, ALP was $478 \mathrm{U} / \mathrm{L}$, Total Protein was $7.00 \mathrm{mg} / \mathrm{dL}$ and the $\mathrm{A} / \mathrm{G}$ ratio was 1.41 . The serum amylase was $212 \mathrm{U} / \mathrm{L}$ and Serum Lipase was $564 \mathrm{U} / \mathrm{L}$. Lipid profile was within normal level (total cholesterol $-180 \mathrm{mg} / \mathrm{dL}$, triglyceride level - $148 \mathrm{mg} / \mathrm{dL}$ and HDL cholesterol - 54 $\mathrm{mg} / \mathrm{dL}$ ). Serum calcium was $8 \mathrm{mg} / \mathrm{dL}$ and Serum LDH was 183 U/L. After 6 days of management at the time of his discharge, the values of S. Amylase was $97 \mathrm{U} / \mathrm{L}$ and S. Lipase $209 \mathrm{U} / \mathrm{L}$ respectively.

Emergency ultrasound examination revealed a bulky pancreas with no pancreatic collection, the gall bladder and bile ducts were reported as normal. The chest X-ray was normal. CECT Abdomen done on the $10^{\text {th }}$ day after the onset of symptoms was found to have diffuse enlargement of the pancreas with a single small fluid collection. CT severity index was $6 / 10$. The patient is still under our followup and reports subsidence of jaundice and regaining of appetite. His liver function tests and pancreatic enzymes showed gradual improvement.

\section{DISCUSSION}

Acute Pancreatitis is a common disease with high morbidity and mortality. Although many infectious agents have been proposed as causing acute pancreatitis, ${ }^{1}$ infectious agents contribute to less than $1 \%$ of the cases. The diagnosis of acute 
pancreatitis caused by an infection requires evidence of pancreatitis, evidence of infection and ruling out other cause of pancreatitis. Acute pancreatitis has been most commonly associated with viruses like mumps, coxsackie, hepatitis A, B and $C$ and several herpes viruses including cytomegalovirus, herpes simplex, varicella zoster, but acute pancreatitis due to HEV is rare.2,3 The first documented case of non-fulminant HEV-associated AP was reported in 1999 by Mishra ${ }^{4}$ et al along with five other cases of HAV-related acute pancreatitis. Till date hardly more than 30 to 50 cases of acute pancreatitis due to hepatitis $\mathrm{E}$ have been reported, out of which the largest series of 16 patients was reported from SGPGI, Lucknow. ${ }^{5}$ Apart from pancreatitis, HEV can also cause extra-hepatic manifestations ${ }^{6}$ such as neurological symptom, kidney injury, haematological manifestation, etc. Most cases of Acute Pancreatitis associated with infection with hepatotropic viruses have been reported in the setting of ALF.

In uncomplicated hepatitis, however, the incidence of pancreatitis is yet to be ascertained. The severity of pancreatic involvement may vary from mild-to-severe. Occurrence of Pancreatitis in the setting of hepatic failure can be explained through several mechanisms, for example pancreatic microvascular ischaemia due to hypotension and disseminated intravascular coagulation, intrapancreatic haemorrhage due to coagulopathy, drugs, sepsis and multiorgan dysfunction or direct injury of pancreatic cell by the hepatotropic virus. Other co-factors such as alcohol abuse, gallstone disease, drugs, trauma, hyperlipidaemia, etc. which may contribute to pancreatitis must be excluded before attributing the illness to hepatitis per se. In our case, none of these above mentioned factors existed. Unusually severe abdominal pain, early in the course of acute hepatitis should alert the clinician to the possibility of associated acute pancreatitis. Early diagnosis of acute pancreatitis complicating acute viral hepatitis may help in reducing morbidity or mortality in such situations.

\section{Key Points}

- Acute pancreatitis is one of the rare extra-hepatic complication of acute hepatitis E.

- Unusually severe abdominal pain early in the course of acute hepatitis should alert the clinician to the possibility of associated acute pancreatitis.

- Institution of treatment if the pancreatitis is recognised early reduces the mortality and morbidity significantly.

\section{REFERENCES}

1. Bhagat $S$, Wadhawan M, Sud R, et al. Hepatitis viruses causing pancreatitis and hepatitis: a case series and review of literature. Pancreas 2008;36(4):424-7.

2. Jain P, Nijhawan S, Rai RR, et al. Acute pancreatitis in acute viral hepatitis. World J Gastroenterol 2007;13(43):5741-4.

3. Dienstag JL. Acute viral hepatitis. In: Longo DL, Kasper DL, Jameson JL, et al. (eds.) Harrison's principles of internal medicine. 19 $9^{\text {th }}$ edn. USA: McGraw-Hill Companies Inc 2015:2004.

4. Mishra A, Saigal S, Gupta R, et al. Acute pancreatitis associated with viral hepatitis: a report of six cases with review of literature. Am J Gastroenterol 1999;94(8):2292-5.

5. Raj M, Kumar K, Ghoshal UC, et al. Acute hepatitis E associated acute pancreatitis: a single center experience and literature review. Pancreas 2015;44(8):1320-2.

6. Bazerbachi F, Haffar S, Garg SK, et al. Extra-hepatic manifestations associated with hepatitis E virus infection: a comprehensive review of the literature. Gastroenterol Rep (Oxf) 2016;4(1):1-15. 